\title{
Wear and superficial roughness of glass ionomer cements used as sealants, after simulated toothbrushing
}

\section{Desgaste e rugosidade superficial de cimentos de ionômero de vidro utilizados como selantes, após escovação simulada}

\author{
Daniela Rios* \\ Heitor Marques Honório** \\ Paulo Amarante de Araújo*** \\ Maria Aparecida de Andrade Moreira Machado****
}

\begin{abstract}
The purpose of this study was to evaluate, in vitro, the properties (wear and roughness) of glass ionomer cements that could influence their indication as pit and fissure sealants. The utilized materials were Fuji Plus, Ketac-Molar and Vitremer (in two different proportions: 1:1 and 1/4:1). The resin-based sealant Delton was used as control. By means of an electronic balance (precision of $10^{-4} \mathrm{~g}$ ), wear was measured in function of weight loss after simulated toothbrushing. Superficial roughness was determined by means of a surface roughness-measuring apparatus. The results revealed that diluted Vitremer and Fuji Plus were less resistant to toothbrushing abrasion and had the greatest increase in superficial roughness. Although in clinical situations luting or diluted ionomer cements are often utilized as alternatives to resin-based sealants, the results of this study revealed that the properties of those cements are worse than those of restorative ionomers, which presented results similar to those of the evaluated resin sealant.

DESCRIPTORS: Pit and fissure sealants; Dental restoration wear; Dental materials.
\end{abstract}

RESUMO: O presente estudo foi conduzido in vitro com o intuito de constatar as propriedades (desgaste e rugosidade) dos CIV, as quais influenciam na sua indicação como material selador de fossas e fissuras. Os materiais empregados foram Fuji Plus, Ketac-Molar e Vitremer (duas proporções: 1:1 e 1/4:1). O selante Delton foi controle. A determinação do desgaste foi obtida através da quantidade de massa perdida após a escovação e a rugosidade através da análise quantitativa da superfície. Os resultados mostraram que o Vitremer diluído e o Fuji Plus apresentaram maior grau de desgaste e maior aumento de rugosidade. Apesar de clinicamente se encontrar um maior uso dos ionômeros de vidro cimentantes ou diluídos como forma alternativa para material selador; este trabalho permitiu concluir que estes possuem propriedades bastante inferiores quando comparados aos ionômeros restauradores que, por sua vez, possuem resultados semelhantes ao selante resinoso.

DESCRITORES: Selantes de fossas e fissuras; Desgaste de restauração dentária; Materiais dentários.

\section{INTRODUCTION}

Occlusal caries constitute approximately 80 percent of the primary lesions in permanent teeth ${ }^{3}$. Although fluoride has reduced the prevalence of dental caries, it has been demonstrated that its protective effect is greater on smooth surfaces than on pit and fissures ${ }^{21}$.

Sealing of pits and fissures is a clinical preventive procedure used to limit occlusal caries ${ }^{21}$. Most of the types of sealant available in the marketplace are resin-based. The preventive effects of this type of sealant are obtained and maintained as long as the material remains completely intact and bonded to the dental surface ${ }^{6}$. Micromechanical retention is provided by the acidic conditioning of enamel prior to the application of sealants. For the adequate retention of the resin-based sealant, at the time of placement the enamel must be clean, free of salivary contamination and dry ${ }^{7,19}$. However, these conditions are rarely possible on recently erupted permanent molars, for which the sealing procedure is indicated.

The glass ionomer cement is an alternative material that may be utilized as a sealant. It presents the desirable property of long-term fluoride release and was introduced in 1974 by McLean, Wilson ${ }^{13}$, who reported $84 \%$ of complete clinical retention after 1 year, and $78 \%$ after 2 years. In their study, wide fissures were selected to allow the placement of thick bulk portions of cement. So far, studies on

*Graduate Student, Doctor's Degree; **Graduate Student, Master's Degree; ***Professor, Discipline of Dental Materials; ****PhD, Professor, Discipline of Pediatric Dentistry - School of Dentistry of Bauru. 
Rios D, Honório HM, Araújo PA de, Machado MA de AM. Wear and superficial roughness of glass ionomer cements used as sealants, after simulated toothbrushing. Pesqui Odontol Bras 2002;16(4):343-348.

the efficacy of GICs (Glass Ionomer Cements) have been carried out, and their results have been conflicting. Some clinical trials reported high success rates $^{12,16}$ (measured through sealant retention), while others report much poorer success rates ${ }^{1,4,17}$. However, an interesting finding is that, as to the reduction of the incidence of caries, the glass ionomer sealant is successful in all studies - it seems to exert a cariostatic effect even after macroscopically removed from the fissure. Long-term retention might not be necessary if the material has anticariogenic properties that increase the resistance of newly erupted fissures to caries ${ }^{1}$.

However, it has been observed that the filling cement could not penetrate fissures narrower than $100 \mu \mathrm{m}^{10}$. As it occurs with other dental restorative materials, the powder-liquid ratio plays an important role in the ultimate physical properties. For glass ionomer cements, the greater the amount of powder, the greater the abrasion resistance and viscosity, and the lower the solubility. High viscosity could negatively affect the ability of the material to flow adequately into the pit or fissure, therefore reducing its sealing ability. To solve this problem, the utilization of flowable GICs has been recommended, in the form of a luting cement or a diluted filling cement. A flowable material penetrates deeper into the fissures, improves retention and also provides longer protection. Machado et al. ${ }^{9}$ carried out a study to examine the effect of diluting a resin-modified glass ionomer (Vitremer with 1:4 powder-liquid ratio) on its clinical performance as a pit and fissure sealant. They reported high success rates after a period of one year, but further research on the physical properties obtained with this different ratio is necessary.

Another factor that should be considered is the low wear resistance of GICs, which may contribute to faster disintegration and thinning of the sealant and, eventually, to its fracture and displacement ${ }^{1}$.

The characteristics of the surface of glass ionomers are also important, since an increase in roughness might result in faster colonization of the surface and faster maturation of plaque, thereby increasing the risk of caries ${ }^{22}$.

The purpose of the present study was to compare, in vitro, the resistance to abrasion and the surface roughness of different forms of glassionomer cements used as pit and fissure sealants: filling (conventional and resin-modified), luting and diluted (modified powder-liquid ratio) forms. Simulated toothbrushing with toothpaste was carried out to predict brushing abrasion.

\section{MATERIALS AND METHODS Experimental design}

The studied materials were glass ionomer cements in four different forms, and a resin sealant was used as control. The experimental sample was composed of 60 specimens randomly assigned to five groups of 12 . The order in which the 12 specimens were prepared was randomly determined. The response variables were wear and superficial roughness, respectively evaluated by means of weight loss and roughness measurements after a toothbrush-dentifrice test.

\section{Specimen preparation}

The materials utilized in this study are presented in Table 1. The instructions of manufacturers were followed for handling the materials, except for Vitremer, which was prepared in a diluted form, with $1 / 4$ of the recommended amount of powder for each drop of liquid. The matrixes (with a $5.0-\mathrm{mm}$ inner diameter and $3.0 \mathrm{~mm}$ of thickness) were slightly overfilled with the materials in a single increment, covered with a polyester strip and a glass slab, and pressed to extrude any ex-

TABLE 1 - Tested materials.

\begin{tabular}{l|l|l|c|c}
\hline \multicolumn{1}{c|}{ Brand } & \multicolumn{1}{c|}{ Manufacturer } & Type & Powder:liquid ratio & Batch number \\
\hline Delton & Dentsply & - & - & 49861 \\
\hline Ketac-Molar & ESPE & Conventional GIC filling & $3.0 \mathrm{~g}: 1.0 \mathrm{~g}$ & SW0048756 \\
\hline Fuji Plus & GC-Corp & Resin-modified luting GIC & $2.0 \mathrm{~g}: 1.0 \mathrm{~g}$ & 160781 \\
\hline Vitremer & 3M Dental Products & Resin-modified filling GIC & $2.5 \mathrm{~g}: 1.0 \mathrm{~g}$ & 19990519 \\
\hline Vitremer $1 / 4$ & 3M Dental Products & Resin-modified GIC diluted for sealing & $0.625 \mathrm{~g}: 1.0 \mathrm{~g}$ & 19990519 \\
\hline \hline
\end{tabular}

GIC = glass ionomer cement. 
Rios D, Honório HM, Araújo PA de, Machado MA de AM. Wear and superficial roughness of glass ionomer cements used as sealants, after simulated toothbrushing. Pesqui Odontol Bras 2002;16(4):343-348.

cess. When necessary, the specimens were cured by means of a visible light-curing unit, following the exposure time recommended by the manufacturers. Ketac-Molar and Fuji Plus were immediately protected using nail polish (Maybelline), and the Finishing Gloss (3M) was used on the Vitremer and $1 / 4$ Vitremer groups. After one hour all the specimens were stored at $37^{\circ}$ in $100 \%$ relative humidity

\section{Initial measurements}

Weighing was carried out by means of an electronic balance (Mettler Toledo - AB 204) every 24 hours until the specimens had a stable weight on five serial measurements, and this value was considered the initial weight. At this time, the analysis surface roughness was quantitatively carried out by means of a surface roughness-measuring instrument (Hommel Tester T1000). Surface roughness was characterized by the height parameter, $\mathrm{Ra}(\mu \mathrm{m})$, defined as the arithmetical average of the absolute values of profile departures in relation to length. The definite initial surface roughness was an average of five initial random measurements of each sample. The cut-off value was set at $0.25 \mathrm{~mm}$.

\section{Toothbrush abrasion}

Subsequently, the specimens were submitted to brushing abrasion in an abrasion testing machine (similar to Pepsodent, made by the Department of Dental Materials, School of Dentistry of Bauru, University of São Paulo). Ten thousand strokes were performed at a speed of 374 strokes (complete forward and reverse movement) per minute, with a load of $200 \mathrm{~g}$, with soft bristles tips (Colgate Classic Infantil - Colgate Palmolive, Division of Kolynos do Brasil Ltda., Osasco, São Paulo, Brazil), in the presence of an abrasive slurry composed of calcium carbonate dentifrice (Sorriso Kolynos do Brasil Ltda., Osasco, São Paulo, Brazil) and distilled de-ionized water in the rate of 1:2 in weight. After brushing abrasion, the specimens were subjected to a new storage period, carried out like the first one.

\section{Final measurements}

Final weight and final surface roughness measurements were obtained after toothbrushing, as described for the initial measurements.

\section{Analysis of wear and superficial roughness}

Wear was measured based on the level of weight loss. It was calculated based on the difference between the initial weight (before tooth brushing) and the final weight (after tooth brushing), for each specimen. The variation of surface roughness was based on the difference between initial and final means, for each specimen.

\section{Statistical analysis}

The results were analyzed by means of the one-way ANOVA criterion and Tukey's test at $\mathrm{p}<0.05$.

\section{RESULTS}

The adjusted mean values (standard error) of the percentage of weight loss (\%) of each one of the five groups are presented in Table 2 . The one-way ANOVA criterion, followed by Tukey's test, revealed differences between the tested materials as to wear resistance.

Vitremer $1 / 4$ presented the highest percentage of weight loss, followed by Fuji Plus and Delton, which did not statistically differ from Ketac-Molar. Vitremer showed the greatest wear resistance and presented no statistically significant difference when compared to Ketac-Molar (Table 2).

ANOVA and Tukey's tests were utilized to evaluate the increase of surface roughness of the materials after the toothbrushing test. The averages between initial and final values of surface roughness of each material are presented in Table 3. An increase in surface roughness was observed in all tested materials after brushing simulation. Vitremer $1 / 4$ exhibited the greatest surface roughness increase, followed by Fuji Plus (Table 3). The other groups did not statistically differ from each other, except for the baseline $(\mathrm{p}<0.05)$.

TABLE 2 - Averages and standard deviations for percentage of weight loss. Results from Tukey's test.

\begin{tabular}{l|c|c}
\hline \hline \multicolumn{1}{c|}{ Material } & $\begin{array}{c}\text { Mean weight loss } \\
(\%)\end{array}$ & Standard deviation \\
\hline Vitremer $1 / 4$ & 5.41333 & 1.034574 \\
\hline Fuji Plus & 4.12227 & 0.690283 \\
\hline Delton & 2.28319 & 1.105618 \\
\hline Ketac-Molar & 1.52472 & 0.420329 \\
\hline Vitremer & 1.26285 & 0.138136 \\
\hline
\end{tabular}

Values connected by vertical brackets did not statistically differ from each other $(\mathrm{p}<0.05)$. 
Rios D, Honório HM, Araújo PA de, Machado MA de AM. Wear and superficial roughness of glass ionomer cements used as sealants, after simulated toothbrushing. Pesqui Odontol Bras 2002;16(4):343-348.

TABLE 3 - Averages of inicial $\left(\mathrm{Ra}_{\mathrm{i}}\right)$ and final $\left(\mathrm{Ra}_{\mathrm{f}}\right)$ superficial roughness $(\mu \mathrm{m})$, averages and standard deviations for the increase of superficial roughness $\left(\mathrm{Ra}_{\mathrm{f}}-\mathrm{Ra}_{\mathrm{i}}\right)$ and results from Tukey's test.

\begin{tabular}{|c|c|c|c|c|}
\hline Material & $\mathrm{Ra}_{\mathrm{i}}(\mu \mathrm{m})$ & $\mathrm{Ra}_{\mathrm{f}}(\mu \mathrm{m})$ & $\mathrm{Ra}_{\mathrm{f}}-\mathrm{Ra}_{\mathrm{i}}(\mu \mathrm{m})$ & Standard deviation \\
\hline Vitremer $1 / 4$ & 0.31 & 0.92 & 0.609667 & 0.309945 \\
\hline Fuji Plus & 0.27 & 0.65 & 0.383667 & 0.080326 \\
\hline Delton & 0.18 & 0.33 & $\Gamma^{0.150667}$ & 0.139777 \\
\hline Vitremer & 0.21 & 0.30 & 0.088500 & 0.116401 \\
\hline Ketac-Molar & 0.37 & 0.41 & ] & 0.107664 \\
\hline
\end{tabular}

Values connected by vertical brackets did not statistically differ from each other $(\mathrm{p}<0.05)$.

\section{DISCUSSION}

The obtained results could not be compared with those of other studies, since no one else has evaluated wear and roughness of materials used as pit and fissure sealants with a comparable methodology.

The rate of abrasion depends on several factors such as the type of dentifrice, the water/dentifrice ratio, the type of brush, and the speed and pressure employed during brushing. However, since in this investigation these parameters were standardized for all groups, the abrasion resistance of the studied materials seems to depend on their inherent properties ${ }^{10}$. Actually, the differences between the materials regarding wear have been reported as the result of a combination of factors ${ }^{18}$. One of such factors is the characteristics of the matrix, which is formed by an acid-base crosslinking reaction of the metal ion-polyacid (conventional GIC), by an interpenetrating polymer network combining the acid-base cross-linking reaction with the cross-linking polymerization of the monomer system, or by an additive action of polymers (resin-modified glass-ionomer cements). Other factors are the ratio and size of glass inorganic particles and the formation of air bubbles while the material is prepared.

Diluted Vitremer was the material most susceptible to abrasion, followed by Fuji Plus, both presenting a flowable constitution. This behavior was already expected because the particles of glass present in the powder determine, to a large extent, the wear resistance of the material ${ }^{15}$, and these materials presented a reduced amount of particles, since they have more liquid. Fuji Plus is originally produced in a diluted form. The manufacturer tried to compensate this dilution by reducing the size of the glass particles, since smaller particles have a larger contact surface area and are consequently more reactive with their admixed acidic polymer. This avoids formation of multiple in-mixed air bubbles ${ }^{5,20}$, justifying its best behavior in relation to the experimental hand-diluted Vitremer $1 / 4$ ionomer.

The resin sealant Delton, in spite of presenting minimum amount of inorganic particles, has a matrix of polymer chains more resistant when compared to the polyalkenoate network, presenting better wear resistance than Fuji Plus. Delton showed no statistically significant difference as to brushing abrasion in comparison with Ketac Molar, which had a wear behavior similar to that of Vitremer. On the other hand, Delton presented wear resistance values that were statistically lower than those of Vitremer.

Resin-modified glass ionomers are reported to have improved mechanical properties ${ }^{11}$. However, there is some controversy regarding the relative abrasion resistance of resin-modified and conventional glass ionomers ${ }^{2}$. Wilson ${ }^{23}$ stated that the hydrogel salt from ionomers and poly-HEMA would be unlikely to interpenetrate, thus forming separate phases, which is not desirable. Moreover, Momoi et al. ${ }^{14}$ reported lower abrasion resistance for the resin-modified material than for the conventional material. However, according to the results obtained in this study, which are in agreement with the results reported by Xie et $a .^{24}$, the conventional and resin-modified GIC presented similar behaviors as to wear resistance.

Since resin-based sealants, which are referential materials concerning retention, present wear resistance similar to or even worse than that of ionomers, one can conclude that brushing abrasion resistance is not the property responsible for the poor retention of ionomer-based materials applied on partially erupted teeth. Other factors, such as poor adhesion to teeth and low resistance to occlusal forces, when teeth are already erupted, 
Rios D, Honório HM, Araújo PA de, Machado MA de AM. Wear and superficial roughness of glass ionomer cements used as sealants, after simulated toothbrushing. Pesqui Odontol Bras 2002;16(4):343-348.

may contribute to the loss of glass ionomer sealants.

The porosity caused by the presence of air bubbles, as well as the filler particles exposed due to abrasion, result on higher roughness. Surface roughness is also influenced by the characteristics of the materials in interaction with several factors, which have been previously explained.

Similarly to what was observed regarding wear, the materials that comparatively presented worse roughness results were the cements containing more liquid than powder (Vitremer $1 / 4$, preceded by Fuji Plus). A possible explanation is that the decrease of glass particles, in these materials, increases their susceptibility to erosion, causing more pronounced displacement of inorganic particles and greater exposure of air bubbles incorporated during mixture ${ }^{5}$.

It is expected that an increase in surface roughness results in faster colonization of the surfaces and faster maturation of dental plaque, thereby increasing the risk of caries, although glass ionomer cements present anticariogenic action due to fluoride release ${ }^{22}$. However, it seems that higher abrasion may provoke loss of surface integrity and the formation of anatomical sites that would encour-

\section{REFERENCES}

1. Aranda M, Garcia-Godoy F. Clinical evaluation of the retention and wear of a light-cured pit and fissure glass ionomer sealant. J Clin Pediatr Dent 1995;19(4):273-7.

2. Creo AL, Viavattine JJ. Comparison of in vitro wear of glass ionomers. [abstract n.947] J Dent Res 1994;73:220.

3. Dodds MW. Dilemmas in caries diagnosis-applications to current practice and need for research. J Dent Educ 1993;57(6):433-8.

4. Forss H, Saarni UM, Seppa L. Comparison of glass-ionomer and resin-based fissure sealants: a 2-year clinical trial. Community Dent Oral Epidemiol 1994;22(1):21-4.

5. Gladys S, Van Meerbeek B, Braem M, Lambrechts P, Vanherle G. Comparative physico-mechanical characterization of new hybrid restorative materials with conventional glass-ionomer and resin composite restorative materials. J Dent Res 1997;76(4):883-94.

6. Gwinnett AJ, Caputo L, Ripa LW, Disney JA. Micromorphology of the fitting surface of failed sealants. Pediatr Dent 1982;4(3):237-9.

7. Gwinnett AJ. Scientific rationale for sealant use and technical aspects of application. J Dent Educ 1984;48(3 suppl.2):56-9.

8. Heath JR, Wilson HJ. Abrasion of restorative materials by toothpaste. J Oral Rehabil 1976;3(2):121-38.

9. Machado MAAM, Hoshi AT, Tironi R, Silva SMB. Evaluation of the enamel pretreatment on the retention of glass io- age the accumulation and stagnation of substrates and microorganisms ${ }^{1}$.

Changes in surface roughness and wear rate cannot entirely predict the clinical behavior of the studied materials. Other aspects, such as depth of penetration, adhesion and marginal microleakage, can more positively account for their clinical performance. Therefore, in vitro models may not necessarily give a full realistic indication of what happens in the mouth. However, considering the high turnover of new materials, the obtained results are important, as well as the results of other laboratorial studies, for predicting the behavior of sealing materials.

\section{CONCLUSIONS}

Under the conditions in which this study was carried out, it may be concluded that:

- The glass ionomer cements which presented flowable consistency (Vitremer $1 / 4$ and Fuji Plus) presented worse properties (wear and roughness) than the restorative ionomers (Ketac-Molar and Vitremer) and the resin-based sealant (Delton).

- Vitremer and Ketac-Molar (restorative ionomers) revealed similar wear resistance and increased surface roughness when compared to the evaluated resin-based sealant (Delton).

nomer cement used as sealant. [abstract n.269] J Dent Res 2000;79(5): 1038.

10. Mair LH, Stolarski TA, Vowles RW, Lloyd CH. Wear: mechanisms, manifestations and measurement. Report of a workshop. J Dent 1996;24(1-2):141-8.

11. Mathis RS, Ferracane JL. Properties of a glass-ionomer/resin-composite hybrid material. Dent Mater 1989;5(5):355-60.

12. Mc Kenna EF, Grundy GE. Glass ionomer cement fissure sealants applied by operative dental auxiliaries - retention rate after one year. Aust Dent J 1987;32(3):200-3.

13. Mc Lean JW, Wilson $\mathrm{AD}$. Fissure sealing and filling with an adhesive glass-ionomer cement. Br Dent J 1974;136(2):269-76.

14. Momoi Y, Hirosaki K, Kohno A, Mccabe JF. In vitro toothbrush-dentifrice abrasion of resin-modified glass ionomers. Dent Mater 1997;13(2):82-8.

15. Navarro MFL, Pascotto RC. Cimentos de ionômero de vidro. In: Navarro MFL, Pascotto RC. Cimentos de ionômero de vidro. São Paulo: Artes Médicas; 1998. p.1-21.

16. Oliveira Júnior OB, Toledo LM, Vida RC, Andrade MF, Porto Neto ST. Avaliação clínica da retenção do cimento de ionômero de vidro utilizado como selante oclusal. Efeito do condicionamento ácido do esmalte. Rev Bras Odontol 1994;51(6):59-63.

17. Raadal M, Utkilen AB, Nilsen OL. Fissure sealing with a light-cured resin-reinforced glass-ionomer cement (Vitre- 
Rios D, Honório HM, Araújo PA de, Machado MA de AM. Wear and superficial roughness of glass ionomer cements used as sealants, after simulated toothbrushing. Pesqui Odontol Bras 2002;16(4):343-348.

bond) compared with a resin sealant. Int $\mathrm{J}$ Paed Dent 1996;6(4):235-9.

18. Sidhu SK, Sherriff M, Watson TF. In vivo changes in roughness of resin-modified glass ionomer materials. Dent Mater. $1997 ; 13(3): 208-13$.

19. Simonsen RJ. Glass ionomer as fissure sealant - a critical review. J Public Health Dent 1996;56(3 special issue):146-9.

20. Smith DC. Development of glass-ionomer cement systems. Biomaterials 1998;19(6):467-78.
21. Stamm JW. Is there a need for dental sealants? Epidemiological implications in the 1980s. J Dent Educ 1984;48 supp12:9-17.

22. Svanberg M, Mjor IA, Orstavik D. Mutans streptococci in plaque from margins of amalgam, composite, and glass-ionomer restorations. J Dent Res 1990;69(3):861-4.

23. Wilson $\mathrm{AD}$. Resin-modified glass ionomer cements. Int $\mathrm{J}$ Prosthodont 1990;3(5):425-9.

24. Xie D, Brantley WA, Culbertson BM, Wang G. Mechanical properties and microstructures of glass-ionomer cements. Dent Mater 2000;16(2):129-38.

Recebido para publicação em02/10/01 Enviado para reformulação em 23/04/02 Aceito para publicação em20/08/02 